\title{
Bubalus arnee Forage under Threat: an Assessment of Koshi Tappu Wildlife Reserve, Nepal
}

\author{
Tej Kumar Shrestha ${ }^{1,2}$, Sunita Shrestha ${ }^{2}$, Saroj Koirala ${ }^{2}$, Anish Parajuli ${ }^{2}$, Pawan Paudyal ${ }^{2}$, \\ Bijaya Mishra $^{2}$, Milan Sapkota ${ }^{3}$, Lok Nath Ghimire $^{4}$ \\ ${ }^{1}$ Khwopa College, Bhaktapur, Nepal \\ ${ }^{2}$ Lumbini Environmental Services Pvt. Ltd., Kathmandu, Nepal \\ ${ }^{3}$ Department of National Parks and Wildlife Conservation, Kathmandu, Nepal \\ ${ }^{4}$ Ministry of Forests and Environment, Kathmandu, Nepal
}

*Corresponding Author: Tej Kumar Shrestha, Khwopa College, Bhaktapur, Nepal, Lumbini Environmental Services Pvt. Ltd., Kathmandu, Nepal

\begin{abstract}
Wild water buffalo (Bubalus arnee) are categorized as endangered on the IUCN Red list, with global population of less than 4000 individuals distributed over less than 20,000 km in Nepal, India, Srilanka, Bhutan, Cambodia, Myanmar and Thailand. In Nepal Bubalus arnee is locally called Arna or Jungali bhainshi is larger and heavier than domestic buffalo weighing from 800 to $1200 \mathrm{~kg}$. They are probably grazers by preference, feeding mainly on grasses, but also eat herbs, fruits, barks and browse trees and shrubs. There were 432 Bubalus arnee in Koshi Tарри Wildlife Reserve in 2016. Threats were identified through literature review and verified during the sample plots survey, questionnaire and expert views. 50 foraging plots were set where fresh dung of Bubalus arnee existed and recorded in survey form. Six potential threats were identified viz flooding, domestic cattle grazing, collection of forest products, invasive plant species, forest fire and shrinking habitat. Flooding and domestic cattle were highly significant threats to the foraging plants. Measures to control threats will perhaps help to protect the human wildlife conflict in the area.
\end{abstract}

Keywords: Bubalus arnee, Koshi Tappu Wildlife Reserve, foraging, Threat, flooding

\section{INTRODUCTION}

The wild water buffalo (Bubalus arnee) called Arna and Jungali Bhainshi in Nepal is a large bovine native to Southeast Asia (Dahmer, 1978) is scheduled as Endangered on the IUCN Red List since 1986 and listed under Appendix III of the Convention on International Trade in Endangered Species of wild fauna and flora (CITES) in Nepal (Hedges et al., 2008). Bubalus arnee is larger and heavier than domestic buffalo weighing from 800 to $1200 \mathrm{~kg}$, with their head to body length of 240 to $300 \mathrm{~cm}$, tail 60 to $100 \mathrm{~cm}$ long and a shoulder height of 150 to $190 \mathrm{~cm}$. The upper elevation limit for the occurrence of Bubalus arnee is difficult to determine, although animals certainly occur down at low lands and feral buffaloes live up to at least 1000 mean sea level in East Java (Dahmer, 1978). Once Bubalus arnee were found throughout the lowland of South Asia, however at present they are found in small range. In Nepal they were recorded in Chitwan valley until 1960, but they were extirpated from that area presumably because of diseases carried by domestic cattle and buffalo (Seidensticker, 1975).

Bubalus arnee are tied to the availability of water and prefer swampy floodplain with tall elephant grass and scrubby woodland forest in the vicinity. They are probably grazers by preference, feeding mainly on grasses when available, but they also eat herbs, fruits, and bark as well as browse trees and shrubs (Aryal et., al., 2011). Several evidences in Nepal and India show that they feed on crops, including rice, sugarcane and jute (Heinen et al., 2006; Aryal et. al., 2011). Shrestha 2017 identified Typha elephantine, Saccharum spontaneum, Tamarix dioica and Phragmites karka as the key plant species preferred by Bubalus arnee. 
Accurate number of purebred Bubalus arnee in Koshi Tappu Wildlife Reserve (KTWR) is still unclear despite various censuses conducted based on morphological rather than genetic study (Aryal et al., 2011). Various researches have confirmed the necessity of conservation action plan for purebred Bubalus arnee to secure them from extinction. They recommended translocation as an essential tool to reduce threats not limited to hybridization, poaching, flooding, disease transmission and lack of ideal space and food (Heinen \& Kandel, 2004; Aryal et al., 2011; Heinen \& Paudel, 2015). KTWR is not free from pressure created by the surrounding community depending for forest products, and grazing cattle inside reserve, which are the main cause for depletion of food, transmitting disease and hybridization causing extinction of purebred population (Heinen, 2002; Aryal et al., 2011). Prompt action needs to be taken to conserve the surviving population in existing habitat by determining various conservation measures (Heinen \& Kandel, 2006; Aryal et al., 2011).

Food resources are often critical regulating factors affecting individual growth and population densities (Aryal et al., 2015). This includes large herbivores as their biomass and health depend upon food availability (Fritz \& Duncan, 1994). Herbivores such as Bubalus arnee face numerous challenges related to food resources and nutrition, including nutritionally imbalanced foods (Wehi et al., 2013; Nie et al., 2014), plant toxin and incompletely digestible fiber (Milton, 1979). An increasing body of research has been devoted to Bubalus arnee including ecology and conflict, population dynamics and general species information and habitat preferences. However, this research focus on identifying the potential threats to the plants preferred by Bubalus arnee in KTWR.

\section{MATERials AND MeTHOdS}

\subsection{Study Area}

KTWR was the only reserve in Nepal with Bubalus arnee existence until few of this species translocated to Chitwan National Park (CNP) in 2016. KTWR was gazetted in 1976 with special objective to preserve Bubalus arnee. The reserve was declared Ramsar site, a wetland of international significance in 1987 (Heinen et al., 1993). KTWR lies on the floodplains of the Saptakoshi river which has vegetation composed mainly of tall grasslands, situated in the South-East terai region of Nepal. The reserve has subtropical climate, with an elevation ranging between $75 \mathrm{msl}$ to $100 \mathrm{msl}$. Chettri et al., 2013 in their 2010 data analysis of KTWR showed agriculture (5\%), forest (1\%), grassland (56\%), lake/pond (0.01\%), Marshes/swamps (6\%), River/stream (10\%) and Sand/gravel (22\%) as land cover types. Their analysis shows that the grassland has increased from $11 \%$ (1976) to $56 \%$ (2010).

The reserve contains important habitat for variety of wildlife including critically endangered Bubalus arnee, river dolphins (Platanista gangetica) and migratory birds (Khatri et al., 2010). There are historical evidences which show that dense riverine forest and tall grasses served good habitat for tiger (Panthera tigris) and leopard (Panthera pardus) (Khatri et al., 2010) however, there are no official information on presence of the carnivores at present (Aryal et al., 2011). The reserve vegetation became thinner due to river bank erosion (Sah, 1997) and the continuous utilization of the area for fuel wood, fodder and livestock grazing by the growing human population in the surrounding villages (Khatri et al., 2010). KTWR is surrounded by villages with low income human population who are directly or indirectly dependent on forest resources (Khatri et al., 2010; Aryal et al., 2011).

\subsection{Methodology}

A total of 50 foraging plots $(5 \mathrm{~m} \times 5 \mathrm{~m})$ were set where fresh dung of Bubalus arnee was directly observed as done by Ngoti, 2017. Dung was located and identified by the help of local resource person working in the study site as a tourist guide who had knowledge of Bubalus arnee and its behavior. Dung was verified by physical observation and its nature for confirmation so that it was not mistaken with dung of domestic cattle. Square plot of $5 \mathrm{~m}$ x $5 \mathrm{~m}$ was measured by measuring tape and set by tying plastic ropes in wooden pegs installed in four corners. Once the plot was set, a survey format was filled up with all the required information for e.g., plot no., observation, presence and absence of cattle, date, GPS coordinates habitat and existing plants following Shrestha et al. 2014.

Potential threats to foraging plant species of Bubalus arnee was identified based on the observation, analysing survey format $(n=50)$ and questionnaire $(n=50)$ collected among the local community. The analysis was literally based in the principle of cause and effect. Literature review and experts' views were also the basis to confirm the potential threats. The survey format was formulated after literature 
review from various sources and modified after Aryal et al., 2015. The threats related to Bubalus arnee were also considered as an important source that could lead to the threats to the plants. Since there was lack of information which directly suggested the threats to plant species, research had to depend on other relevant threats such as threats to Bubalus arnee, threats to KTWR and threats to biodiversity that existed in KTWR. Survey format contained information that could be analysed for threats to plants for e.g.; domestic cattle presence/absence, distance from the reserve boundary, and distance from river, grazing activities, forest fire incidence, etc. The information collected during survey of foraging plots performed the main basis of threats identification. Other basis was the analysis of secondary information, for e.g.; population trend of Bubalus arnee would shrink the habitat causing competition for palatable species, etc. Suggestions from experts and key person were also reviewed and identified as threats of potential plants. Threats to plants were analysed using SPSS version 20.

\section{RESULTS AND DISCUSSION}

50 foraging plots were set purposively inside reserve where fresh dung of Bubalus arnee existed. Most of the plots occurred in the grassland followed by shrub land based on the occurrence of the fresh dung sample.

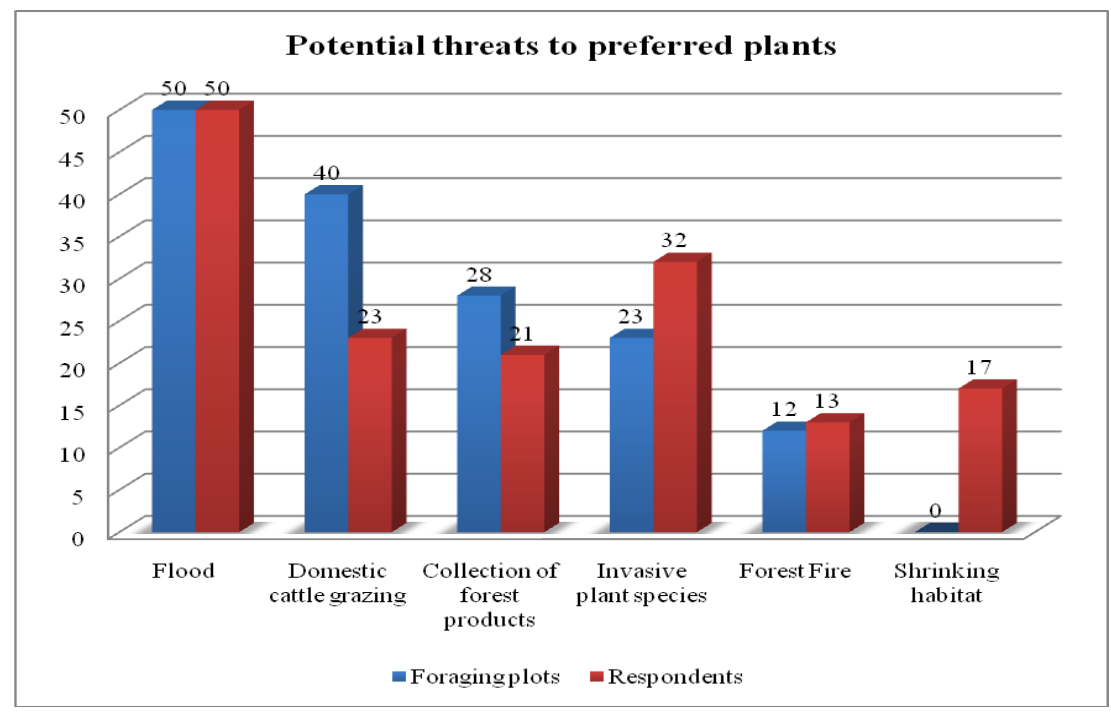

Figure1. Potential threats to preferred plants of Buballus arnee

Six potential threats were identified from this research. Five specific potential threats were identified from the data analysis of information collected from foraging plots survey format $(n=50)$. Flood, domestic cattle grazing, collection of forest products, invasive species and forest fire incidence were recorded while shrinking habitat due to population increase was identified after literature review. Based on finding from foraging plots survey, literature review, identified six different potential threats were included in questionnaire and surveyed among local people from the buffer zone of KTWR buffer zone. Data collected from survey format and questionnaire collection were then analysed. This analysis showed that flooding was recorded in entire plots and was also accepted by entire 50 respondents. It was observed that threats from domestic cattle grazing and forest product collection had indifference result from two methods. Survey showed that domestic cattle grazing and collection of forest products occurred in 40 and 28 plots while some of the respondents rejected these threats and only 23 (domestic cattle grazing) and 21 (forest product collection) accepted as potential threats. In contrast Invasive species and forest fire have increased in respondents' response. Shrinking habitat due to increase in population of Bubalus arnee was accepted by 17 respondents which was not part of foraging plots survey. Reduction of palatable plants for Bubalus arnee forced this animal to invade in agriculture farm for food, causing human buffalo conflict in the area.

Each identified potential threats are discussed in following sections.

\subsection{Flooding}

This threat was identified based on the information collected from survey format and consultation with experts. Most of the forage plots lied close to the Saptakoshi river banks which had high risk of 
flooding and thus swept the plants nearby. Entire plots lied within 100 meters from the river with low altitudinal range making area sensitive of flooding. During the questionnaire, entire respondents suggested that flooding is one of the major causes of threat to Bubalus arnee and its habitat. Flooding trend also shows that there were frequent flooding activities in the KTWR damaging flora and fauna of the KTWR (Khatri et al., 2010). The Koshi river changed its course in 2008 swinging from the main channel to the eastern part of the reserve, that had a dramatic change in the physical landscape such as loss of forest and grassland (Khatri et al., 2010). Continuous flooding inside the reserve has been destroying the grassland and wildlife habitat that further reduces the volume of palatable species (Aryal et al., 2011).

\subsection{Domestic Livestock Grazing}

Domestic livestock grazing inside the reserve is also serious threats (Aryal et al., 2011) both for Bubalus arnee and its forage plants. During the survey there were presence of cattle or the residual effects of the domestic cattle in the area such as dung and hoof prints. Out of 50 plots direct observation of cattle grazing, dung and pellets of domestic animals were recorded in 40 plots. Domestic buffalo were directly observed grazing inside the core area of reserve and fresh and old dung of domestic buffalo presence in the area also suggested that the area was invaded by domestic livestock. During survey, domestic buffalo was major invaders followed by cow and goats. However, respondents rejected that domestic grazing was as serious as was recorded in the survey. Only 23 respondents accepted this as a potential threat. This research is also supported by Heinen, 2008 which reported that villagers grazed large numbers of tended cattle and buffalo inside the reserve. Many of these domestic animals were kept in semi wild or tended, free ranging state to crossbreed with wild males in expectation that hybrid calves would in return give them higher price (Heinen, 1993). This has caused competition for palatable plants among wild water buffalo and domestic livestock. Disease and parasites transmitted by domestic livestock can be also serious threats to Bubalus arnee (Aryal et al., 2011; Heinen \& Paudel, 2015).

\subsection{Unsustainable Harvesting of Forest Products}

KTWR office allows collection of forest products such as grass for thatching, fodder for cattle and fuel wood for domestic use, which is legally allowed in seasonal basis (Khatri et al., 2010). However, the pressure of local community is so high that they enter reserve illegally for collection of grass, and other forest products with no restriction of season (Heinen \& Kandel, 2008). Local people use Saccharum spontaneum, Typha elephantine, Phragmites karka for thatching and fodder (Heinen, 1993b). Similarly, Chryspogon aciculatus, Cynodon dactylon, Tamarix dioica, Eleusine indica are preferred fodder plants for livestock. Uncontrolled and over harvesting of plants from the reserve reduces the quantity and quality of plants that are preferred by Bubalus arnee (Aryal, 2011).

\subsection{Invasive Species}

Biological invasion threatens biodiversity, ecosystem dynamics, resource availability, national economy and human health. It is a pervasive and costly environmental problem (Larson et al., 2001). Invasive species such as Chromolaena odorata, Eupatorium adenophorum, Lantana camara, Mikania micrantha are found in KTWR (Siwakoti, 2009) which are becoming problematic for the management (Aryal et al., 2011; Chettri et al., 2013). Mikania inherent traits of invasiveness and is an extremely serious weed with an exceptionally fast growth (Choudhary, 1972) that damages or kills other plants by preventing light and smothering them. It also competes for water and nutrients, but perhaps even more importantly, it releases substances that inhibit the growth of other plants (Ye and Xia, 2001). Invasive species were recorded in 23 plots out of 50 foraging plots surveyed. It was interesting that Mikania micrantha recorded to be consumed by Bubalus in 10 survey plots, which is one of the key invasive species. However, this weed has been creating a serious threat in the native vegetation and been threat for all sorts of plants including Bubalus forage species (Khatri et al., 2010). 23 respondents informed that invasive species were also key threat for the habitat and plants of Bubalus. It is understandable that local perceived threats from all types of invasive plants in the KTWR.

\subsection{Forest Fire}

Illegal entrance of local farmers to the reserve for collection of forest products has increased the likelihood of fire incidence in the grassland. There were records of forest fire incidence in 12 plots 
during the survey. Due to the uncontrolled forest fire frequently has changed the composition of the forest structure resulting replacing preferred species by less preferred ones. Most of indigenous plant species are more sensitive to forest fire and takes longer to grow back to its original states (Aryal et al., 2011).

\subsection{Shrinking Habitat}

Population trend of Bubalus arnee shows that the number is increasing from 63 individuals when it first established in 1976 up to 432 in 2016; consequently, increased population of Bubalus has reduced the space from 2.78 Sq.km to 0.41 Sq.km per individual Bubalus. If the area covered by water bodies, agricultural and sand and gravel and marshes are deducted then the available space would decrease significantly. The shrinkage in the habitat has impact on the quantity and quality of available food for Bubalus (Aryal et al., 2011). Besides, rise in population has created over grazing of palatable species and has thus chance of extinction of those plants. In other side human pressure is increasing and the demand for resources from reserve is also increasing, habitats for the globally significant species are thus shrinking (Hedges, 1995; Aryal et al., 2011).

\section{Conclusion}

Six potential threats for plant species preferred by Bubalus arnee were identified viz, flooding, domestic livestock grazing, collection of forest products, forest fire, threats from invasive species, and shrinking habitat. Flooding was the most significant threats to the forage of Bubalus arnee followed by the invading by domestic cattle inside the reserve. Unsustainable harvesting of forest products specially the grass for various domestic purpose by the local also threatens the loss of foraging plants. Introduction of invasive flora reduces the volume of preferred plants. Although low, forest fire also threatens the forage plants for the Bubalus in KTWR. Shrinking habitat has caused competition among the Bubalus arnee for palatable species within the KTWR, which forces them to invade in agriculture land that causes the human wildlife conflict. Measures are to be implemented to protect the forage plants of this bovine from threats. Further understanding the nutritional preferences, the nutritional characteristics of available foods and protection of potential plants from threats will provide information that may help reduce human wildlife conflict.

\section{ACKNOWLEDGEMENT}

This research was possible due to support and permission provided by Department of National Parks and Wildlife Conservation and Koshi Tappu Wildlife Reserve. The author wants to acknowledge Rufford Small Grant, UK, Keidanren Nature Conservation Fund, Japan, Idea Wild, USA, Lumbini Environmental Services Pvt. Ltd., and Nature First Nepal for their financial and equipment support for this research.

\section{REFERENCES}

Aryal, A., Shrestha, T.K., Ram, A., Frey, W., Groves, C., Hemmer, H., Dhakal, M., Koirala, R.K., Heinen J.T., and Raubenheimer, D. 2011.Call to Conserve the Wild Water Buffalo (Bubalus arnee) in Nepal. International Journal of Conservation Sciences 2 (4):161-168.

Aryal, A., Coogan S.C.P., Ji, W., Rothman, J.M., and Raubenheimer, D. 2015. Food macronutrients and fibre in the diet of blue sheep (Psuedois nayaur) in the Annapurna Conservation Area of Nepal. Ecology and Evolution 5 (18):4006-17.

Chetri, N., Uddin, K., Chaudhary, S., and Sharma, E. 2013. Linking Spatio Temporal Land Cover Change to Biodiversity Conservation in the Koshi Tappu Wildlife Reserve, Nepal. diversity (5):335-351.

Choudhury, A. K. 1972. Controversial Mikania (climber) a threat to the forests and agriculture. Indian Forester (98):178-186.

Hedges, S. 1995. Asian Wild Cattle and Buffalo: Draft Status Report and Conservation Action Plan (Parts I and II), Unpublished report, IUCN Gland, Switzerland.

Hedges,S., Baral,H.S., Timmins,R.J., Duckworth,J.W. 2008. Bubalus arnee, in IUCN Red List of Threatened Species, Version 2011.1. <www.iucnredlist.org>.

Heinen, J.T. \& Kandel, R. 2004. A Census and Conservation Action Plan for wild buffalo in Nepal. DNPWC and IUCN-Nepal, Kathmandu.

Heinen, J.T. \& Paudel, P.K. 2015. On the translocation of wild Asian buffalo Bubalus arnee in Nepal: Are feral backcrosses worth conserving? Conservation Science (3):11-21. 
Heinen, J.T. 1993. Population viability and management recommendations for wild water buffalo (Bubalus bubalis) in Koshi Tappu Wildlife Reserve, Nepal. Biological Conservation, 65, 29-34.

Heinen, J.T. 2002. Phenotypic and behavioral characteristics used to identify wild buffalo (Bubalus bubalis) from feral backcrosses in Nepal, Journal of Bombay Natural History Society, 99, (2): 173-183.

Heinen, J.T., Kandel, R. 2006. Threats to a small population: a census and conservation recommendations for wild buffalo Bubalus arnee in Nepal, Oryx, 40, (3):1-8.

Heinen,J.T., Singh, G.R. 2001. A census and some management implications for wild buffalo in Nepal, Biological Conservation, (101): 391-394.

Khatri,T.B. Shah,D.N., Tachamo Shah, R.D., Mishra,N. 2010. Biodiversity of Koshi Tappu Wildlife Reserve: A post flood assessment, Journal of Wetlands Ecology (4):69-82.

Larson, D.L., Anderson, P.J. and Newton, W. 2001. Alien invasion in mixed-grass prairie: Effects of vegetation type and anthropogenic disturbance. Ecol Appl. (11): 128-14.

Milton, K. 1979. Factors influencing leaf choice by howler monkeys: a test of some hypotheses of food selection by generalist herbivores. Am. Nat. (114): 363-378.

Ngoti, P.M. 2017. Feeding ecology of eastern black rhinoceros (Diceros bicornis michaeli) in souther Serengeti National Park, Tanzania. MS Thesis, Norwegian University of Science and Technology, Norway.

Nie, Y., Z. Zhang, D. Raubenheimer, J. J. Elser, W. Wei, and F. Wei. 2014. Obligate herbivory in an ancestrally carnivorous lineage: the giant panda and bamboo from the perspective of nutritional geometry. Funct. Ecol. (29):26-34.

Sah, J.P. 1997. Koshi Tappu Wetlands: Nepal's Ramsar site. IUCN Southeast Asia Regional Coordination Office, Bangkok, Thailand.

Seidensticker, L. 1975. Ungulate Population in Chitwan Valley, Nepal. Unpublished Report, Office of Zoological Research, National Zoological Park, Smithsonian Institution, Washington, DC, USA.

Shrestha T.K., A. Aryal, R. Rai, S. Koirala, Y.B. Thapa, D. Jnawali, R. Kafle, B.P. Bhandari, D. Raubenheimer. 2014. Balancing Wildlife and Human Needs: Protected Forest Approach in Nepal. Natural Areas Journal 34(3):376-380.

Siwakoti, M. 2009. An overview of floral diversity in wetland of terai Region of Nepal. Our Nature (4):83-90.

Wehi, P. M., D. Raubenheimer, and M. Morgan-Richards. 2013. Tolerance for nutrient imbalance in an intermittently feeding herbivorous cricket, the Wellington Tree Weta. PLoS ONE (8): 84641.

Ye, W. H. and Xia, Z. (2001). The plant killer-Mikania micrantha in South China. Aliens (13): 7

Citation: Tej Kumar Shrestha, et al., "Bubalus Arnee Forage under Threat: An Assessment of Koshi Tappu Wildlife Reserve, Nepal", International Journal of Research Studies in Zoology, vol. 4, no. 3, p. 22-27, 2018. http://dx.doi.org/10.20431/2454-941X.0403004

Copyright: () 2018 Authors. This is an open-access article distributed under the terms of the Creative Commons Attribution License, which permits unrestricted use, distribution, and reproduction in any medium, provided the original author and source are credited. 